\title{
The Independence of the Trustee as an Organ Formed by the Public Company
}

\author{
Muhammad Reza Syariffudin Zaki ${ }^{1, *}$, Agus Riyanto ${ }^{1}$, Okta Auliazahara ${ }^{1}$ \\ ${ }^{1}$ Business Law Department, Faculty of Humanity, BINUS University \\ Jl. K. H. Syahdan No. 9 Kemanggisan / Palmerah Jakarta Barat $11480+62.21534$ 5830, +62.21 5350660 Fax. \\ $+62.215300244$ \\ *Corresponding Author email: rezaszaki@gmail.com
}

\begin{abstract}
Research on the independence of the trustee as an organ formed by the public company aims to find out about (1) how the independence of the trustee appointed by the public company; and (2) who should appoint a trustee in the framework of independency of the trustee. This study uses a normative legal research method that functions to provide juridical argumentation when there is emptiness, obscurity, and conflict in legal norms. The data in research obtained through library research and explanatory analysis. From the research results, it is known that (1) the trustee appointed by the public company is not independent; and (2) the party that should name a trustee in the framework of independency of the trustee is the bondholder whose interests are represented by the trustee.
\end{abstract}

Keywords: Independence, Trustee, Public Company

\section{INTRODUCTION}

In Indonesia, the capital market has developed very rapidly. The rapid development of the capital market is marked by a large number of listed companies or issuers on the stock exchange. Stock exchanges are established to conduct regular, fair, and efficient securities trading (Wijaya \& Ananta, 2018, p. 20) [1]. In order to achieve this goal, the stock exchange is required to provide supporting facilities and watch the activities of members of the stock exchange. There's only one stock exchange in Indonesia, Indonesia Stock Exchange (IDX) or Bursa Efek Indonesia (now referred to as 'BEI'). OJK noted that there were 510 issuers in 2015, while in 2019, there were more than 640 issuers. The issuer listed its company on the IDX intending to be able to sell its securities to securities buyers. [2] (Otoritas Jasa Keuangan, 2020)

Securities themselves are regulated in Law No. 8 of 1995 concerning Capital Markets (now referred to as "UUPM"). Article 1, number 5 of the Capital Market Law, states that what includes securities are debt acknowledgment, commercial papers, shares, bonds, proof of debt, units of collective investment contracts, futures contracts, and any underlying products of securities.

The definition of debt or bond is not explicitly regulated in the Capital Market Law (UPPM). But even so, the notion of bonds can be seen in the regulations issued by the Surabaya Stock Exchange. PT Surabaya Stock Exchange Regulation No. IA
(Attachment to the Decision of the Directors of PT Surabaya Stock Exchange Number SK-017 / LGL / BES / XI / 2004 dated November 25, 2004, concerning General Provisions for Listing of Securities) explains the conditions for securities to be categorized as debt: (1) can or cannot be converted or exchanged into equity securities; (2) issued in the rupiah and foreign currencies; (3) issued by the private sector, State-Owned and Regional-Owned Enterprises, Cooperatives, Central or Regional Governments, and other parties that have received effective statements from the Capital Market Supervisory Agency (now referred to as "Bapepam").

A public bond offering is a bond offering activity carried out by issuers to sell their bonds to the public. Bond sales are based on procedures set out in the Capital Market Law and other regulations regarding their implementation. The public offering is carried out by BEI. BEI acts as the place where issuers meet as bond sellers, with investors as bond buyers. Bond buyers or investors in a public offering are investors who want to invest in getting profits from the issuer. Issuers, who benefited from bond buyers, must undoubtedly be able to protect the interests and rights of bond buyers. To protect the interests and rights of bond buyers, the issuer needs the support of a capital market supporting institution, the trustee.

The definition of the trustee is regulated in Article 1, Number 30 of the Capital Market Law, which reads "the trustee is the party representing the 
interests of debt holders." Also, the definition of a trustee is regulated in Law No. 10 of 1998 concerning Amendments to Law No. 7 of 1992 concerning Banking (now called the 'Banking Law') in Article 1 number 15 . Article 1 number 15 of the Banking Law explains that trustees are business activities that can be carried out by commercial banks to represent the interests of holders of securities based on agreements between commercial banks and the issuer concerned. According to Article 50, paragraph (1) of Law Number 8 of 1995 concerning Capital Market, commercial banks are one of the parties that can carry out activities as trustees. In addition to commercial banks, other parties that have been determined by Government Regulation can become trustees.

The role of the trustee to represent the bondholders inside and outside the court resulted in granting authorization from the bondholders to the trustee. Although assigning the power is given by the bondholders, the one who appoints the trustee is not carried out by the bondholders. The appointment of the trustee is carried out by the issuer [3] (Jono, 2004, p. 49).

The appointment of a trustee is conducted before the issuer makes a public offering. The public bond offering cannot run if the issuer has not appointed a trustee who will represent the bondholders. Bondholders cannot name a trustee because, at the time of the appointment, there were no bondholders. The absence of bondholders at that time occurred because at the time the appointment was made, the bonds had not been offered to prospective investors or prospective bond buyers through a public offering of bonds. Before the bonds are offered to potential investors through a public offering, issuers have appointed who they trust to represent the bondholders as trustees. Trustees appointed by the issuer to act on behalf of the bondholders are bound by an agreement. The agreement made was named as a trustee agreement.

A trusteeship agreement is an agreement made between the issuer and the trustee. Provisions requiring issuers and trustees to make trusteeship agreements are regulated in Capital Market Law Article 52, which states: "Issuers and trustees must make a trusteeship contract following the provisions stipulated by Bapepam."

A trusteeship agreement is contrived and signed after the appointment of the trustee. The trustee who has signed the trusteeship agreement is assumed to have been agreed and is committed to representing the bondholders. The representative can only be valid when the bonds have been allocated to investors.

The trustee will be responsible for provide compensation to holders of debt securities for losses due to negligence in carrying out its duties which include: A payment of principal and / or debt interest effects, Payment of due fines and other matters contained in trusteeship contract. [4] (Pakpahan et al., 2018, p. 468)

The trustee, as a capital market supporting institution, is required to be able to be independent and neutral in representing and protecting the interests of bondholders. The claim against the independence of the trustee cannot be carried out if the issuer is the one who appoints the trustee.

Trustees are not only appointed by the issuer but also paid by the issuer. This case causes the trustee to work to two sides. The first side is the side of the trustee, who is bound by a trusteeship agreement, appointed and paid by the issuer. But on the other hand, the trustee must also be able to protect the interests of bondholders. That is the reason why trustees cannot possibly be independent. If the trustee cannot be independent, the trustee may not be able to represent and provide maximum protection to the bondholders. This paper aims to (1) know and analyze the trustworthiness of the trustee in the Indonesian capital market and (2) find out who should appoint a trustee in the framework of the trustee's independence

Based on the problems in the background above, the writer will raise two main issues in writing this thesis as follows: (1) How is the independence of the trustee appointed by the issuer? And (2) Who should appoint a trustee to guarantee the independence of the trustee?

\section{METHODS}

In the research process of this journal, the authors use data collection techniques obtained based on literature studies. A literature study is an activity to gather information related to the topic or problem that is the object of research. Such data can are obtained through books, scientific papers, theses, dissertations, and other literary sources.

The results are presented in the form of reports. The report will be produced following laws and any other legal sources. These legal sources will be well investigated using explanatory research typologies, from which the results of this report will be explained about the independence of the trustee appointed by the issuer and the actual party considered appropriate to appoint a trustee 
The legal relationship between the issuer and the trustee is different from the issuer and the bondholder. The legal basis for the relationship between the issuer and the trustee is in the trustee agreement. From this trusteeship agreement, it can be seen that the existence of a trustee is a party that receives power from bondholders that do not yet exist. There are no bondholders because the new bonds will be sold after the agreement is signed.

The trusteeship agreement involves two parties, namely the trustee and the issuer. The trustee is a representative of prospective bondholders who has not yet been identified. Meaning, the prospective bondholder who wants to buy the bond has given a power of attorney to the trustee. The granting of power of attorney carried out by the bondholders will undoubtedly lead to rights and obligations for both the giver and the proxy.

The trustee becomes the representative of the bondholders under the law (Article 51 paragraph (2) of the Capital Market Law). The representation will have a legal effect. The legal consequences arising from the authority received by the representative is being able to act for and on behalf of the people represented. The law does not directly regulate the general jurisdiction of the trustee by only mentioning "representing inside and outside the court." This authority was obtained after the signing of the trusteeship agreement.

TABLE 1. Research Methods

\begin{tabular}{|c|l|l|l|}
\hline No & \multicolumn{1}{|c|}{ Questions } & \multicolumn{1}{c|}{$\begin{array}{c}\text { Data } \\
\text { Collection } \\
\text { Techniques }\end{array}$} & Sources \\
\hline 1. & $\begin{array}{l}\text { How is the } \\
\text { independence } \\
\text { of the trustee } \\
\text { appointed by } \\
\text { the issuer? }\end{array}$ & $\begin{array}{l}\text { Secondary } \\
\text { Data with } \\
\text { Who should } \\
\text { appoint a a } \\
\text { trustee to } \\
\text { guarantee the } \\
\text { independence } \\
\text { of the } \\
\text { trustee? }\end{array}$ & $\begin{array}{l}\text { Studies } \\
\text { Secondary } \\
\text { Legal } \\
\text { Materials }\end{array}$ \\
\hline
\end{tabular}

\section{RESULT AND DISCUSSION}

The independent attitude of the trustee is explained in Article 51 of the Capital Market Law. In Article 51 of the Capital Market Law, it is defined that the independence of the trustee is carried out to avoid a conflict of interest. Conflict of interest, in this case, is a situation where the trustee has a relationship other than the trusteeship relationship with the issuer. Examples are credit relationships and affiliate relationships. Article 51 of the Capital Market Law explains that trustees are prohibited from having a credit relationship or affiliation with the issuer. However, it's also told that affiliation relations are only allowed to occur if the ownership or participation is in the Government capital.

The relationship between the trustee's credit and the issuer is regulated in Rule Number VI.C.3. In Rule Number VI.C.3, it is explained that in conducting activities in the capital market, trustees are prohibited from doing two things, namely: (a) Having a credit relationship with the issuer in the amount of more than $25 \%$ (twenty-five percent) of the amount of debt and/or sukuk securities that are authorized; and/or (b) concurrently becomes the guarantor and/or collateral in the issuance of debt securities, sukuk and/or issuer's obligations and becomes the trustee of the securities holder issued by the said issuer.

In this case, the interests of bondholders can only be maximally fulfilled if the trustee can carry out his duties and functions independently. One example case regarding the trustee's credit relationship with the issuer is between PT. Bank Negara Indonesia, Tbk. (BNI) with the Pegadaian Corporation (Pegadaian). As reported in 2010, BNI resigned as a trustee of Pegadaian bonds, the resignation was carried out because BNI planned to provide credit for Pegadaian worth of Rp3 trillion, which made the value of the credit loan exceeded the $25 \%$ of the bonds that were allowed. At that time, when BNI resigned at the trustee, the total obligations held by BNI reached around Rp1.7 trillion.

If BNI did not resign from its position as trustee, BNI would have been violated Article 51 paragraph 3 of the Capital Market Law Number VI.C.3 regarding the independence of the trustee. BNI would not have been able to show its independence as a representative of the Bondholders, and this would have impacted the duties and functions of the trustee.

The independence of the trustee does not only come in the form of a credit relationship between the trustee and the issuer but also the type of affiliate relationship. In Article 51 paragraph (1) of Capital 
Market Law, it is explained that the independence of the trustee referred is to avoid a conflict of interest between the trustee and the issuer. In this position, the trustee, as the representative of the bondholders, must be able to protect the bondholders to the fullest extent by not having an affiliation relationship with the issuer.

Affiliate relationships between trustees are strictly prohibited. However, there are exceptions to this affiliation relationship. The exception is that affiliation can be made as long as it occurs due to ownership of government capital. According to Article 1, point 4 of Government Regulation (PP) of Republic of Indonesia Number 1 of 2008 concerning Government Investment. Government capital participation is a form of government investment in business entities in return for obtaining ownership rights, including the establishment of limited liability companies (LLC) and/or takeover of limited liability companies (LLC).

The ban is applied to avoid conflict of interest between the trustee as the representative of the bondholders and the issuer. Where, in this case, an issuer is a place where the trustee has an affiliation (Iswi Hariyani \& Octa, 2010, p. 109) [5]. The affiliation relationship is a relationship between the issuer as a company and the trustee as another party. Issuers can indirectly control the trustee through the trusteeship agreement.

In addition to being asked to side with bondholders, the ban is also carried out so the trustees could carry out their functions independently. By doing this, the trustee can protect the interests of bondholders completely.

The appointment of the trustee is made by the issuer. The selection can be seen in Rule Number VI.C.4. Issuers appoint trustees before a public offering [2] (Jono, 2004, p. 49). The appointment of the trustee is carried out by the issuer rather than by the bondholder. That is because, at the time when the trustee was appointed, there were no bondholders. New bondholders will present after the public offering is completed while the trustee is appointed by the issuer before the public offering is made. Before the public offering in question is when the bonds have not been offered to the public.

According to Article 1, number 26 of Law Number 8 of 1995 concerning the Capital Market, the appointment of trustees made before the public offering held can also be seen from the prospectus made by the issuer. A prospectus is any written information in connection with a public offering with the aim that other parties buy securities. From this understanding, it can be seen that the prospectus contains information about the issuer that will conduct a public offering.

In the prospectus issued by the issuer, there is information about the trustee. Article 11, letter c POJK No. 9/2017, explains that in the prospectus, there is a section on public offerings. In the public offering, there is information about name, address, and description of the party acting as trustee. So it can be seen that the trustee has been appointed by the issuer before the prospective bond buyer.

After the appointment of the trustee by the issuer is made, it is needed to make a trusteeship agreement. The trusteeship agreement must be made by the issuer and trustee based on the provisions stipulated by Bapepam. Article 5 letter o of Capital Market Law states that Bapepam can "provide further technical explanations of this Law or the implementing regulations." a) The replacement of the trustee must be based on specific reasons. Bank business license as trustee is revoked; b) Revocation or suspension of trustee business activities in the capital market; c) A trustee is dissolved by a judicial body or by another official body that has disbanded in the eye of the law; d) Trustees are declared bankrupt by the competent judicial body or have their operations and/or business activities frozen by the competent authority; e) Trustees cannot carry out their obligations; f) Trustees violate the trusteeship agreements and/or regulation in the capital market sector; g) The affiliation relationship between the trustee and the issuer arises after the appointment of the trustee unless the affiliation occurs due to ownership or participation of government capital; $h$ ) The emergence of a credit relationship that exceeds the amount regulated in Rule Number VI.C.3., or i) At the request of debt holders.A trustee replaced for any of the above reasons or any other reasons will terminate his duties, obligations, and responsibilities. The termination of burdens will apply after a new trustee is appointed.

The issue regarding the appointment of a trustee carried out by the issuer is not the only problem that becomes an obstacle to the independence of the trustee. Other obstacles can hinder the independence of the trustee. These constraints are regarding payment of trustee services fees. The payment of trustee services fees is another authority issued by the issuer to the trustee [6] (Aritonang, 2008, p. 67)

The amount of service fees for the trustee is stated in the letter of appointment of the issuer to the trustee. If in the period of service, the trustee is dismissed or replaced by another trustee, the fees of 
the trustee for that year will be returned proportionally.

Payment of services for trustees paid by the issuer can cause a problem. The problem is related to the bond between the issuer and the trustee because this relationship can later influence the independence of the trustee.

The importance of these problems is because the main task of the trustee is to be representative of the bondholders. By being that, the trustee is also required to watch over the issuer. The appointment as a trustee is equivalent to getting a business opportunity from the issuer for a commercial bank. That is because, until now, not all commercial banks are trustees. The issuer, on the other hand, has the power to determine who it wants to be appointed to be the trustee.

According to $\mathrm{R}$. La Porta in the Journal of Financial Economics, Legal permits granted by a country have two characteristics, viz opposed and prohibited (sanctions). The most obvious legal protection form is the existence of enforcement institutions laws such as courts, police and outside dispute resolution agencies other (non-litigation) courts. [7] (Porta et al., 2000) This is in line with the understanding of the law according to Soedjono Dirdjosisworo who stated that the law has understanding diverse in society and one of the most tangible of notions about law is the existence of law enforcement institutions. [8] (Dimyati, 2014, p. 342)

Theory of Legal Protection is one of the important theories for society. Weak people ask for legal protection both economically and in terms of aspects juridical. The form of legal protection is in the form of preventive and repressive measures.Preventive means that the government must take policies and decisions withinterms of preventative measures. While protection is repressive, it means the governmentmore firm in making decisions about violations and sanctions given by the perpetrators. [9] (Pakpahan et al., 2019, p. 307)

A trustee carried named by the issuer does affect not only the independence of the trustee but also the legal protection of bondholders. Legal protection for bondholders exists because of a legal relationship.

The legal relationship, in this case, occurs between the issuer, trustee, and bondholders. The legal relationship between the issuer and the trustee is also a legal relationship between the bond issuer and the party representing the prospective bond buyer. The relationship between the two begins with the obligation of each issuer who wants to issue bonds To be able to issue bonds, the issuer appoints one independent party. The party is the trustee. The trustee, in this case, is assigned as a representative of the bondholders. [11] (Sili, 2016, p. 199)

The responsibilities of the trustee are not only based on the law but also on the trusteeship agreement. The trusteeship agreement is a benchmark for the relationship between the issuer, trustee, and bondholder. The Trusteeship Agreement also serves as a benchmark for the extent of legal protection for bondholders.

Legal protection granted to bondholders by the trustee should be done correctly. It can be counted accurately if all the rights and obligations of bondholders have been fulfilled, and the trustee has carried out his duties, functions, and authority thoroughly. However, a problem arises before the trustee can perform the duties, functions, and authority to carry out legal protection for bondholders, and that is the appointment of a trustee carried out by the issuer.

The appointment of the trustee by the issuer is held prior to the signing of the trusteeship agreement where it is done before the public offering is made, whereas the new bondholders will be available after the public offering is completed. So, at the time of the appointment of the trustee, there are no bondholders because the public offering has not yet been made.

As a result of the absence of bondholders at the time of appointment or trusteeship-agreement making, the bondholders must swallow the issuer's decision unanimously. In addition to having to that, the bondholders also are not given any opportunity to directly negotiate the terms of the trusteeship. With this, it can raise doubts about whether the legal protection of bondholders can be offered by the trustee. The doubt arises from when the appointment of the trustee carried out by the issuer even before the bondholders exist.

The trusteeship agreement that must be obeyed by the trustee also stipulates the rights of bondholders, including the interest payment rights, principal payment rights, the right to obtain collateral information, the right to know the bond rating, the right to sue and others.

If the issuer is in breach of default or violation of the limitations and obligations written in the trusteeship agreement, the trustee has to work actively. Active in this case is reporting events that occur to bondholders and making efforts so that issuers can correct these violations.

Issuers will certainly correct their mistakes. But if the time given to the issuer to correct its errors has been exceeded, the trustee will be able to summon 
the bondholders. The summons was made to hold a RUPO with the plan to discuss the violations committed by the issuer. In Article 51, paragraph (2) of Law Number 8 of 1995 concerning the Capital Market says that if after the RUPO held still does not produce a settlement, the trustee must confront the issuer to fight for the rights of bondholders through litigation and non-litigation.

Trustees dealing with issuers through litigation and non-litigation channels will experience difficulties in terms of financing such litigation and non-litigation processes. In terms of financing, the fees received by the trustee have been provided by the issuer. In order to ensure maximum and independent protection, trustees are required to prioritize the interests of bondholders. However, if financial support is not given, the trustee cannot carry out his duties in protecting the interests of bondholders and independently. It proves that the trustee is still financially dependent on the issuer. With trustees still financially dependent on the issuer, trustees cannot be independent.

The trustee, as a capital market supporting institution, is required to be able to be independent and neutral. Trustees needed to be able to represent and protect the interests of bondholders. The independence of the trustee is not achievable if the appointment of the trustee is still carried out by the issuer. The problem is that not only the trustee appointed by the issuer but also paid by the issuer. However, in carrying out its duties, the trustee should side with the bondholders.

The appointment and payment of service fees done by the issuer will have an impact on the work of the trustee. The effect obtained apart from the trustee being not independent is that the trustee also cannot provide full legal protection to bondholders.

The appointment of the trustee is regulated in Rule Number VI.C.4. In this regulation, the first appointment of a trustee is carried out by the issuer and will be valid until the end of the term or end of the trustee's contract. In the case of the termination of the duties before fulfilling its interest and penalties (if any), the trustee shall remain in the office until a new trustee is appointed. At the time of this new appointment, there are already bondholders. With the existence of bondholders, the selection will be carried out by the RUPO. RUPO is a forum or meeting between bondholders and issuers.

The appointment of the trustee has always been made by the issuer. In a study of the trusteeship agreement pattern in Indonesia in 2004, it could be seen that there was an article stating the appointment of the issuer to certain parties to carry out their duties as trustees. [6] (Aritonang, 2008, p. 88)

The payment of trustee services fees has always been paid by issuers. Payment of service fees made by the trustee is stated in the issuance appointment letter to the trustee [6] (Aritonang, 2008, p. 88). The amount and implementation process regarding the payment of service fees stated in the letter of appointment of the issuer to the trustee.

The appointment and payment of trustee services fees made by the issuer have long occurred. The issuer explains that at the time of appointment and making the trusteeship agreement (which also regulates payment of trustee services), there are no bondholders yet.

The impact is the trustee's dependence. The party that is most affected by the independence of the trustee is the bondholder. The effect that the bondholders receive simply is the inability of the trustee to represent and protect the interests of the bondholders. In this case, the trustee is bound by the issuer to be able to do things that benefit the issuer.

The trustee is currently in an independent state, and this situation needs to be corrected. The improvements must be made on behalf of the bondholders. Once it is done, the interests of bondholders will be fully ensured.

An independent trustee, according to the author, is a trustee who does not depend on the issuer both directly or indirectly. Dependency can be directly seen from the payment of trustee services, whereas indirect dependency can be seen from the bonds established on the appointment of the trustee carried out by the issuer.

The trustee indepenency which does not depend on the issuer also has a concept similar to the independence of the judiciary power. Independence for judicial authority is one of the basic principles that must be followed by countries based on law. [10] (Hakim, 2018, p. 281)

The independence of the trustee can occur if the trustee is free and does not favor the issuer. In order to be independent, the trustee should not be chosen by the issuer. Responding to this, the author believes that the RUPO should choose the trustee. As explained, the RUPO is a meeting forum held to bring the two parties-bondholders and issuers together.

Bondholders can choose or appoint their elected trustees through the RUPO. The appointment of a trustee made not by a bondholder may result in a trustee not being independent. Because ultimately, the trustee is the party representing the bondholders rather than the other party. Another problem that will 
arise is how to fulfill all the requirements to make a public offering when the bondholders only come after the public offering is completed. Because if one of the conditions is not fulfilled, the issuer cannot conduct a public offering of bonds.

One of the requirements to be able to make a public offering of bonds is the presence of a trustee. A trustee must exist before a public offering of bonds. The existence of a trusteeship before a public offering of bonds aims to convince potential bond buyers to want to buy the bonds. Meanwhile, the prospective bond buyers can only legally become bondholders after the public bond offering is completed. The author believes that if this issue is to be overcome, a temporary trustee is needed.

Temporary trustees chosen by issuers or OJK can be directly appointed as permanent trustees by bondholders. This appointment will be carried out through the RUPO. Through RUPO, bondholders can directly select a temporary trustee to become a permanent trustee if seen eligible.

If the bondholders in the RUPO do not approve to change the status of a temporary trustee to become a permanent trustee, there must be a replacement. These candidates will be proposed by the parties. Bondholders can propose candidates for permanent trustees instead of temporary trustees, and so can the issuer. Issuers can also nominate a name for potential trustees. But the decision remains in the hands of bondholders.

A trustee who has been appointed as a trustee can do his duty as a representative of the bondholders until the end of the period, or until there is the newly trustee chosen as a substitute for the permanent trustee.

The holding of a temporary trustee is expected to provide independence for the trustee. The independence of the trustee can be carried out because the trustee, in this case, does not have any ties with the issuer. In addition, trustees can be more independent because they favor the bondholders, so the rights of bondholders will be well protected.

In addition to this method, permanent trustees can also be appointed through the RUPO mechanism. General Meeting of Bondholders or RUPO is a meeting forum created to bring together bondholders and issuers. The meeting is usually held for a specific purpose. Rule Number VI.C. 4 states that the RUPO may be held for the following purposes: a) to make decisions in relation to the issuer's or observer's recommendations regarding changes of time, principal loan bonds, interest rates, changes in procedures or the period of interest installment, guarantee or allowance for sinking funds and other provisions in the trusteeship agreement; b) to give notice to the issuer and/or trustee, give direction to the trustee and/or approve the time concession based on a trusteeship agreement and its consequences, or to take other actions related to negligence; c) to dismiss the trustee and appoint a replacement trustee according to the provisions of the trusteeship agreement; d) to notify, just in case, the trustee plans to take other actions which are not authorized or not in a trusteeship agreement or based on statutory regulations; and e) to take steps authorized by or on behalf of the bondholders, including in determining the potential for negligence that may cause based on the trusteeship agreement and in Rule VI.C.4.

It can be seen from the purpose of holding the RUPO above, that the agendas are already in the trusteeship agreement. A trusteeship agreement is a guideline for conducting RUPO. RUPO held based on the trusteeship agreement, which makes the RUPO is not included in the organ structure of the company.

RUPOs can be submitted by bondholders, which possesses more than $20 \%$ (twenty percent) of the total outstanding bonds, issuers, trustees, and Bapepam. The purpose of conducting RUPO according to Rule Number VI.C.4 is divided into 2 (two), namely amendment to the agreement and not an amendment to the agreement.

In the case of the first RUPO, which aims to change the agreement requested by the issuer, must be held in the presence of bondholders or represented by at least 3/4 (three quarters) of the total principal amount of the bond that has not been repaid and has the right to make legal and binding decisions and approved by at least 3/4 (three quarters) of the total principal of the bonds. The second RUPO, held to change the agreement requested by the issuer, has the same requirements as the first RUPO. Unlike the first and second RUPO, in the third RUPO, it can be held if attended by bondholders or represented at least 3/4 (three quarters) of the total principal amount of the bond that has not been paid and has the right to take legal and binding decisions agreed by at least $1 / 2$ (one per two) part of the principal amount of the bonds present in the RUPO.

In the case of the RUPO, intending to change the agreement requested by the trustee or the bondholder has different requirements with the one requested by the issuer. The first RUPO, which aims to change the agreement requested by the trustee or bondholder must be attended by the bondholders or represented at least $2 / 3$ (two thirds) of the total principal amount of the bond that has not yet been settled and has the 
right to make a valid and binding decision and agreed by at most a half (one half) portion of the total principal of the bonds present in the first RUPO. In the second and third RUPOs, whose aim is to amend the agreement requested by the trustee or bondholder, have the same conditions as the first RUPO. Same as when requested by the trustee or bondholder, the RUPO requested by the OJK has the same terms as the first, second, and third RUPO.

In the RUPO, bondholders are determinants of the RUPO results because the ones who are entitled to vote are bondholders. Bondholders who are entitled to attend and vote are bondholders who have a KTUR. KTUR stands for "Written Confirmation for Meeting." The meeting, in this case, is RUPO.
KTUR itself has the meaning as a letter of confirmation of ownership of bonds issued by KSEI (Indonesian Central Securities Depository) to bondholders through account holders, specifically for the need to attend the RUPO or submit a request to hold a RUPO.

The trustee himself has a particular task in carrying out the RUPO. The trustee here acts as the party in charge of coordinating the RUPO. In addition to coordinating the RUPO, the trustee also leads the RUPO. The trustee is also required to prepare the RUPO program, RUPO materials, and appoint a Notary who must prepare the minutes of the RUPO.

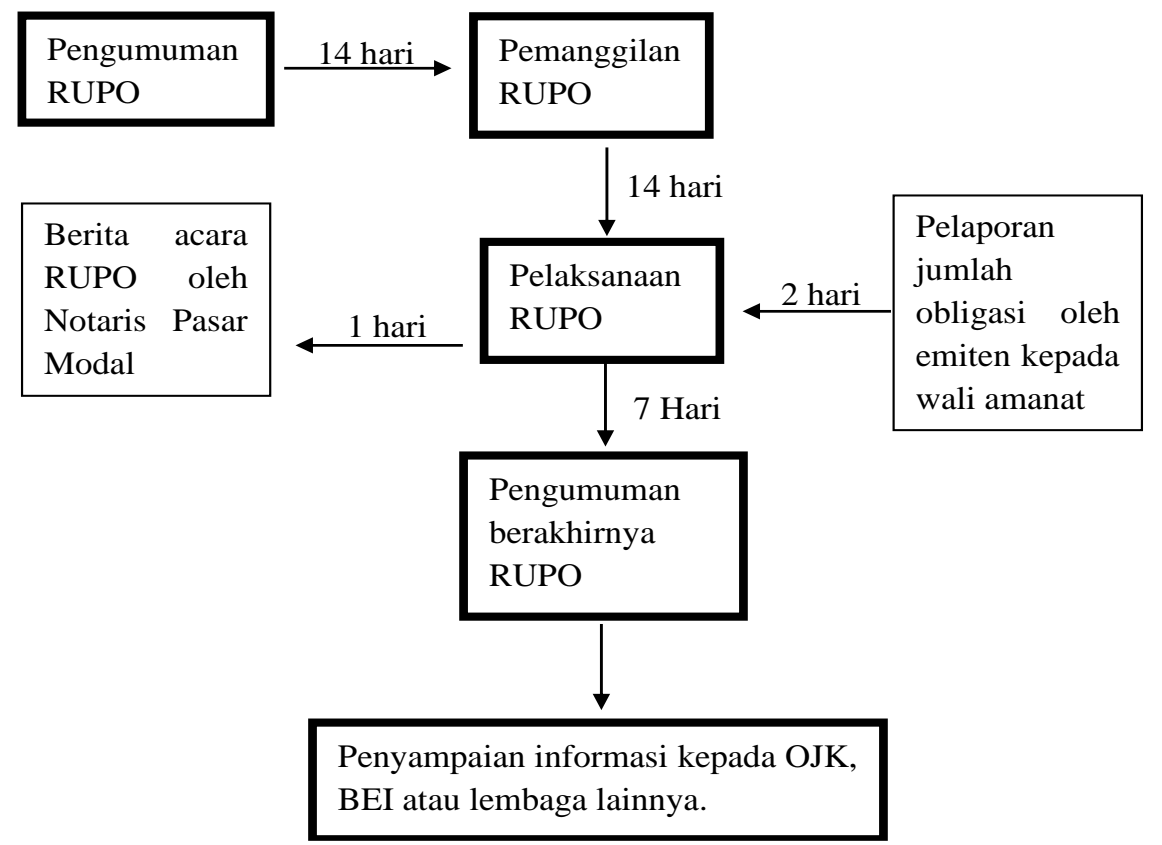

FIGURE 1: the RUPO program

Figure 1. In figure above, it can be seen that the actual RUPO can be held with the plan of appointing a permanent trustee. The purpose of this RUPO is to select a trustee who is in line with the aspirations of the bondholders. Bondholders can provide wishes or name prospective trustees if the temporary trustee is not considered appropriate to represent. The implementation of the RUPO must be in line with the procedures of doing the RUPO

Bondholders through the RUPO will produce a determination, which is the result of the voting of bondholders. The results of the voting of bondholders must be following the provisions of the RUPO quorum. Thus, the appointment of a permanent trustee carried out by the RUPO will make the trustee more independent.

Another problem that worth to be discussed is the payment of trustee services. Payment of trustee services fees is currently still being made by issuers. As already explained, the trustee cannot be independent if it still has a bond with the issuer. Whereas payment of trustee services from the past to the present is carried out by the issuer. It can be seen that this causes trustees not to be independent

To be independent, the issuer should not pay the trustee services fees. The better party to pay the trustee services is the party who is benefited from the 
trustee. The party that takes benefits from having a trustee is the bondholder.

As a party benefited by a trustee, it is appropriate for bondholders to pay compensation for the services of the trustee. If the bondholder does not want to pay for the services of the trustee, OJK must pay for the services of the trustee.

The trustee cannot be paid by the issuer if it dreams of achieving the independence of the trustee. Meaning, another party is needed to make payment for the services of the trustee. In this condition, the other party is OJK. OJK can make payment for trustee services. With the amount of money paid for trustee services fees by the OJK, however, for the payment of trustee services fees, it is not allowed to use government budget funds provided to the OJK but should be from the annual fees paid by the issuer.

The trustee receives payment of compensation for his services from OJK. Where OJK gets funds to pay the trustee from the annual listing fees and the recording of bonds paid by the issuer to the IDX. This condition shows that the issuer does not make payments for trustee services, with OJK as the party who pays, it can help to achieve the independence of the trustee. The implementation of the trustee's independence occurs because the payment of trustee services is not carried out by the issuer but through the OJK.

The appointment and payment of trustee services made by the issuer are actually one of the issues that must be carefully examined. The impact of this problem is the independence of the trustee. By being dependent, it will affect the performance of a trustee in protecting the bondholders in full. Seeing this condition, the author, as explained above, believes that the appointment of a trustee should be carried out by the RUPO. And so is the payment of services fees. The payment of trustee services fees should be made by the OJK so that trustees will remain independent.

As trustees become more independent, the rights of bondholders become more protected. By protecting the rights of bondholders, it can provide incentives and enthusiasm for investors to invest more in bonds. In addition to protecting the rights of bondholders, the trustee can also offer maximum performance. With this maximum performance, trustees can reduce the level of negligence and violations that occur. Trustees also do not need to be torn apart.

\section{CONCLUSION}

The selection of trustees carried out by the issuer will not create the independence of the trustee.
Independence happens because when they are appointed, there are no bondholders yet. Bondholders are present when the bond's public offering is complete, while the trustee is already there before the bond's public offering takes place. In addition to the appointment of a trustee, the issuer also pays compensation services for the trustee. With this payment, the trustee will indirectly have an affiliation with the issuer. This affiliate relationship can be seen from the existence of a trusteeship agreement signed by the issuer and trustee even before the presence of bondholders. Meanwhile, the trusteeship agreement is made to protect the interests of bondholders.

The ones who should appoint a trustee to create the independence of the trustee are bondholders. The bondholder, as the entity, whose interests are represented by the trustee, has the right to choose the trustee himself. However, because the new bondholders exist after the public bond offering, the temporary trustee is needed. The temporary trustees can later be appointed as permanent trustees through the RUPO if found eligible. In the RUPO, bondholders can vote according to the quorum to determine the permanent trustee who will represent the interests of bondholders. To be able to represent the interests of bondholders independently, the payment of trustee services fees should be made by bondholders. If bondholders are not willing, OJK can take its role.

\section{REFERENCES}

[1] A Wijaya and W P Ananta 2018 IPO Right Issue \& Penawaran Umum Obligasi (Jakarta: Sinar Grafika) p. 20

[2] Otoritas Jasa Keuangan 2020 Emiten dan Perusahaan Publik (Jakarta: OJK) p. 20 p. 49

[3] Jono 2004 Indepedensi Wali Amanat dalam Memberikan Perlindungan Kepada Para Pemegang Obligasi Law Review FH UPH 4 (1) 49

[4] E F Pakpahan, Leonard T and H Heriyanti 2018 Reconstruction of Decision Bapepam-LK N0. 412/BL/2010 Concerning on The Trustee Contract Jurnal Pembaharuan Hukum 5 (3) 468

[5] Iswi Hariyani and Octa W 2010 Buku Pintar Hukum Bisnis Pasar Modal (Jakarta: Visimedia) p. 109

[6] Aritonang, M I 2008 Pelaksanaan Tanggung Jawab Wali Amanat Dalam Penerbitan Obligasi di Pasar Modal (Semarang: Diponegoro University) p. 67 p. 88 
[7] R L Porta, Lopez de Silanes, A Shleifer, and R Vishny 2000 Investor Protection and Corporate Governance Journal of Financial Economics 25

[8] Dimyati H H 2014 Perlindungan Hukum Bagi Investor dalam Pasar Modal Jurnal Cita Hukum 2 (2) 342

[9] E.F Pakpahan, T T Simbolon, F Lovano, E Elisah, and G Thomasia 2019 Konsep Perlindungan Hukum terhadap Wali Amanat di Pasar Modal Jurnal Hukum Samudera Keadilan 14 (2) 307

[10] Muh R Hakim 2018 Tafsir Indepedensi Kekuasaan Kehakiman dalam Putusan Mahkamah Konstitusi Jurnal Hukum dan Peradilan 7 (2) 281

[11] E B Sili 2016 Perlindungan Investor Obligasi di Pasar Modal melalui Pendekatan Etika Bisnis bagi Penerbit Obligasi Jurnal Hukum \& Pembangunan 46 (2) 199 